\title{
Performance of World Health Organization as a Green Building
}

\author{
K. Hassouneh ${ }^{a}$, A. Al-Salaymeh ${ }^{b}$, and A. Sakhrieh ${ }^{c}$ \\ ${ }^{a}$ Architecture Engineering Dept., Faculty of Engineering \& Technology, The University of Jordan, Amman, Jordan \\ ${ }^{b}$ Mechanical Engineering Dept., Faculty of Engineering \& Technology, The University of Jordan, Amman, Jordan \\ ${ }^{c}$ Department of Mechanical and Industrial Engineering, American University of Ras Al Khaimah, UAE
}

\begin{abstract}
The rapidly growing world energy use has already raised concerns over supply difficulties, exhaustion of energy resources and heavy environmental impacts. The global contribution from buildings towards energy consumption has steadily increased. Jordan relying on importing more than (97\%) of its oil needs. The household in Jordan consumes $43 \%$ of the total electricity produced. The current situation enforces us to have more efficient use of energy in this sector. For this reason, energy efficiency in buildings is today a prime objective for energy policy at national and international level. The Jordanian buildings codes such as the Jordan green building code were developed to face energy challenges that Jordan has recently encountered. In residential sector, energy is used for equipment and appliances that provide heating, cooling, lighting, water heating, and other household demands. In this study, an efficient energy building has been selected and studied. The present study concentrates on the one of the energy saving examples, which is Green building represented in the World Health Organization (WHO) building in Amman. A comprehensive study of energy consumption in the building has been carried out. A comparison between the Jordanian regular buildings and the current building was made; EnergyPlus was used to make all calculations. It is found that the WHO building saves $23.9 \%$ of the total energy saved from HVAC systems, and widely dependent on the natural lighting. WHO reduces the Greenhouse gases emissions of $\mathrm{CO} 2$, about $57563.12 \mathrm{~kg}$ of $\mathrm{CO} 2 \mathrm{were}$ reduced, which helps in the global warming.
\end{abstract}

\section{Introduction}

Green building is a structure that is designed, built, renovated, operated, or re-used in an ecological and resource efficient manner. Green building reduces negative environmental effect [1]. Residential, commercial and industrial buildings use about $45 \%$ of the nation's energy including $75 \%$ of the nation's electricity. Air pollution from these fuels imposes considerable health, environmental and property damage costs. When we reduce our use of conventional energy in buildings, we lower emissions of pollutants. The pollution produced not only contributes to global warming, but the acid rain produced is reintroduced into our rivers, streams, oceans and eventually back to us through the water we use and the fish and plants we eat.

Leadership in Energy and Environmental Design (LEED) is a set of rating systems for the design, construction, operation, and maintenance of green buildings, homes and neighborhoods [2]. Category Aspects [3], Site Development, Water Efficiency, Material Selection, Indoor Environmental Quality, Innovation in Design, Regional Priority and Energy Efficiency Buildings are classified for Four Levels: (1) Certified: 40-49 points, (2) Silver: 50-59 points, (3) Gold: 60-79 points, and (4) Platinum: 80 points and above.

\section{Goals of the Study}

- General study about Green buildings.

- Studying the energy performance of the world health organization (WHO) building in Amman, Jordan, which has a gold LEED certificate;

- Investigating its impact on the environment, and making a comparison between the green building and the usual Jordanian building;

- Performing an energy simulation for this building on ENERGY PLUS application;

- Rating the building according to the Jordanian green building guide.

\section{Case Study, WHO}

World Health Organization is established in 2011. It is located in the capital city of Jordan, Istiklal Street, next to Jamal Abdel Nasser square; it has area around $3422.39 \mathrm{~m}^{2}$, four stories tall with 120 employees. The WHO shares the building with the Regional Center for Environmental Health Activities (CEHA). Fig 1,2

* Corresponding author

E-mail: k.hassouneh@ju.edu.jo

(C) 2016 International Association for Sharing Knowledge and Sustainability

DOI: $10.5383 /$ ijtee. 11.01 .006 


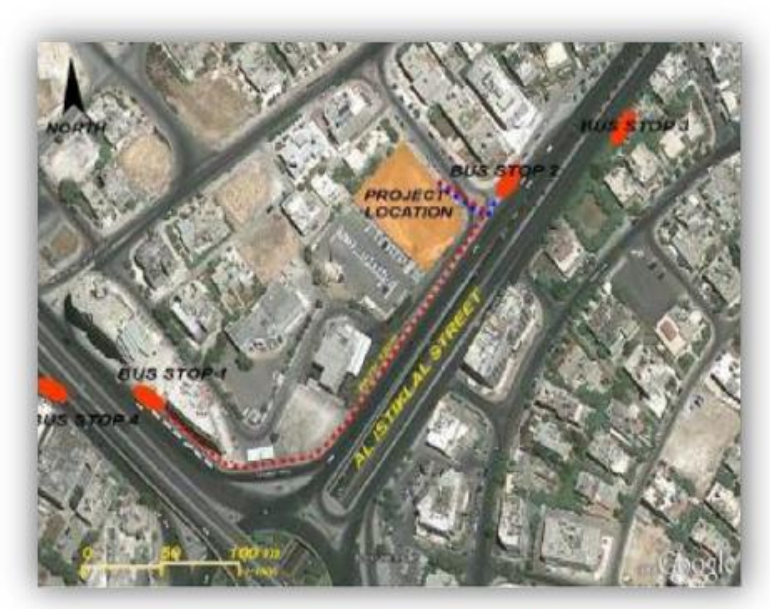

Fig 1. Site location [4]

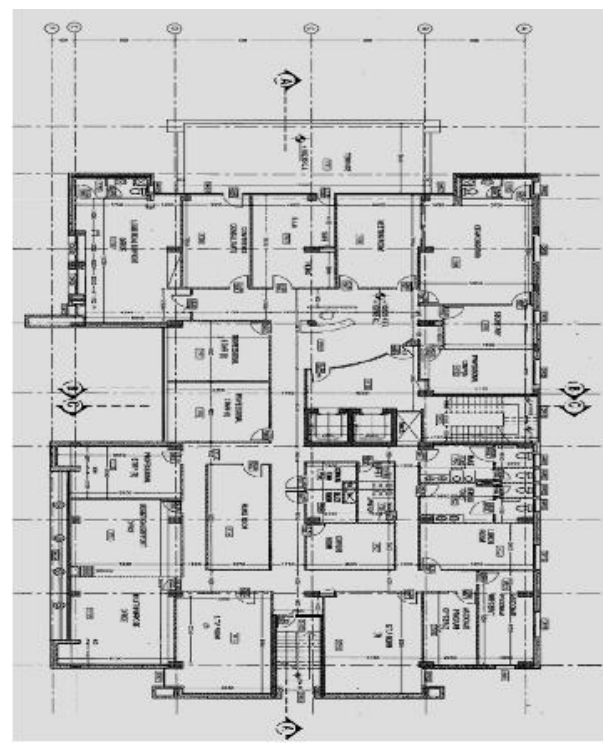

Fig 2. WHO Scheme

\section{Goals of WHO}

1) Professional environment that provides the highest standards of health.

2) To be consistent with the neighborhood, community and the surrounding environment.

3) To be a model for the health conservation and the environment by reducing the environmental impacts of poor health and through higher economic returns.

4) To be a tool to raise environmental awareness.

\section{WHO as a green building}

The WHO was awarded the LEED Gold Certificate as a first LEED gold certification in Jordan and some of its advantages is [5]

\section{- Day lighting maximization}

- Over $45 \%$ of the materials used for construction were regional/local materials and throughout the construction process.

- Builders converted $78 \%$ of the construction wastes from the landfill

- The WHO focused on reducing pollution and waste throughout the entire building process.

WHO got 68 Points Based on Jordanian Building Guide. [6]

\section{HVAC System}

HVAC is shortcut for Heating, Ventilating and Conditioning. In case of WHO building design, the engineers were concerned in energy saving in other words A Green building. For a building with this size, the most convenient HVAC system to use was VRF Variable refrigerant flow (VRF) is an HVAC technology. [7] Like ductless mini-splits, VRFs use refrigerant as the cooling and heating medium. This refrigerant is conditioned by a single outdoor condensing unit, and is circulated within the building to multiple fan-coil units (FCUs). [8] Fig 3.

This also results in greater control of the building's interior temperature by the building's occupants.

VRFs come in two system format, two pipe and three pipe systems. In a 2-pipe system, all of the zones must be either all in cooling or all in heating. A three pipe Heat Recovery (HR) systems has the ability to heat certain zones while others require cooling. In this case, the heat extracted from the zone requiring cooling is put to use in the zone requiring heating. This is made possible because the heating units are functioning as a condenser providing sub-cooled liquid back into the line that is used by for cooling. While the 3-pipe system has a greater initial cost, it allows for zone greater thermal control of building and overall greater efficiencies. [9]

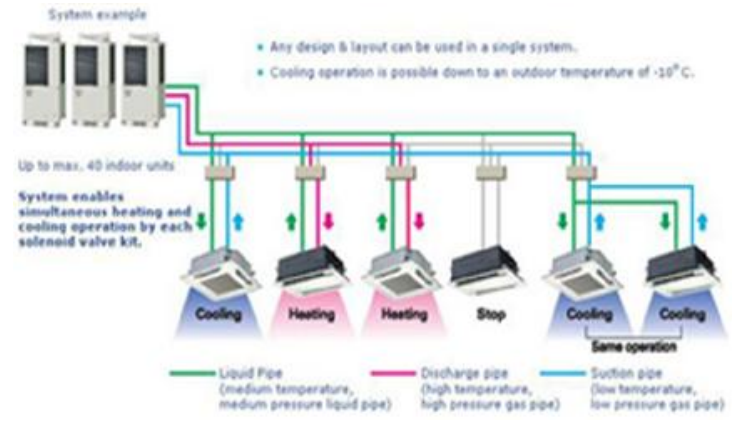

Fig 3. VRF Scheme. [10]

\section{Energy Plus [11]}

EnergyPlus is an energy analysis and thermal load simulation program. Based on a user's description of a building from the perspective of the building's physical make-up, associated mechanical systems, etc., EnergyPlus will calculate the heating and cooling loads necessary to maintain thermal control setpoints, conditions throughout an secondary HVAC system and coil loads, and the energy consumption of primary plant equipment as well as many other simulation details that are necessary to verify that the simulation is performing as the actual building would.

Weather file is an input file of the EnergyPlus. It provides a ready-to-use data for a specific city such as exact location, daily temperatures and solar radiation values for a year. 


\section{Energy Saving Measures}

In saving energy, certain measures were taken:

1) Extruded polystyrene foam was used as an insulation material to reduce heat transfer through walls with the thermal properties.

2) Low overall coefficient of heat transfer for windows: Using coated 12-mm clear glass plate followed by another 6-mm plate with air gap of 13-mm thick. Which lead to an overall coefficient of heat transfer of $1.9 \mathrm{~W} / \mathrm{m}^{2} .{ }^{\circ} \mathrm{C}$.

3) Building Orientation: In relatively hot climate regions such as Jordan, The large south aspect of the building was tilted 45 degrees clockwise to maximize the daylight with keeping heat gain at a reasonable range

4) Lights: in lighting manners the following measures were applied:

- Motion detectors were used to minimize energy usage.

- Take maximum advantage of daylight to reduce electric lighting hours.

- Fluorescent lighting that has high efficiency was used.

- Sun bathes were created in walls to make internal areas such as corridors be naturally lighted.

- LEED lights

- PV cells were used to operate exterior lights.

5) Equipment: By using high efficient equipment that have excellent energy label (A and above) energy can be saved.

6) Conserving Water: In WHO a high efficient tabs and toilets had used they used a toilets that consumes 3.5 liter per flush and a tabs that consume 3 liter per minute and all of it working by LASER motion detectors.

\section{Results}

- Site and Source Energies

Source energy represents the total amount of raw fuel that is required to operate the building. It incorporates all transmission, delivery, and production losses. By considering all energy use, the score provides a complete assessment of energy efficiency in a building.

Figure 4 demonstrate SOURCE and SITE energies, while Figure 5 shows Annual total site and source energies for regular and the green building.

\section{Detailed Energy Consumption}

Since the building is divided to various areas, some of these areas don't require Air Conditioning such as corridors, storages, filing rooms, etc. these areas are considered as a single zone named "NO-LOAD ZONE". Figure 6 displays conditioned and unconditioned areas.

An active building like WHO's could need to be expanded in the future, a cost estimation will be required. Therefore Figure 7 shows energy consumption per area for both conditioned and unconditioned areas which help in estimating energy costs in future.

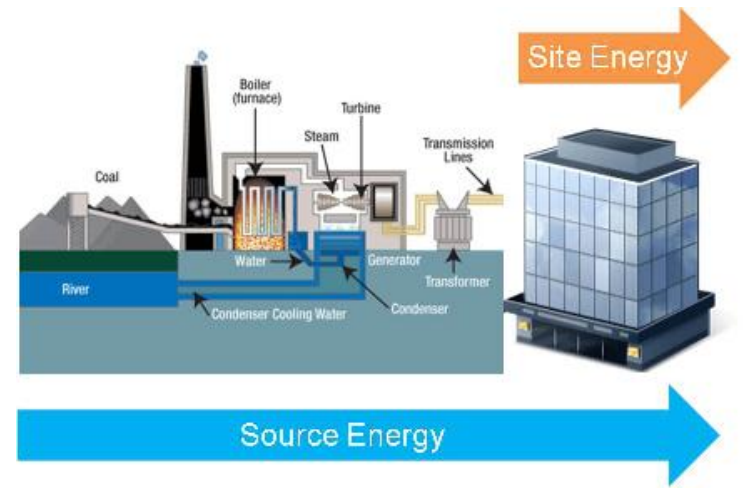

Fig 4. SOURCE and SITE Energies

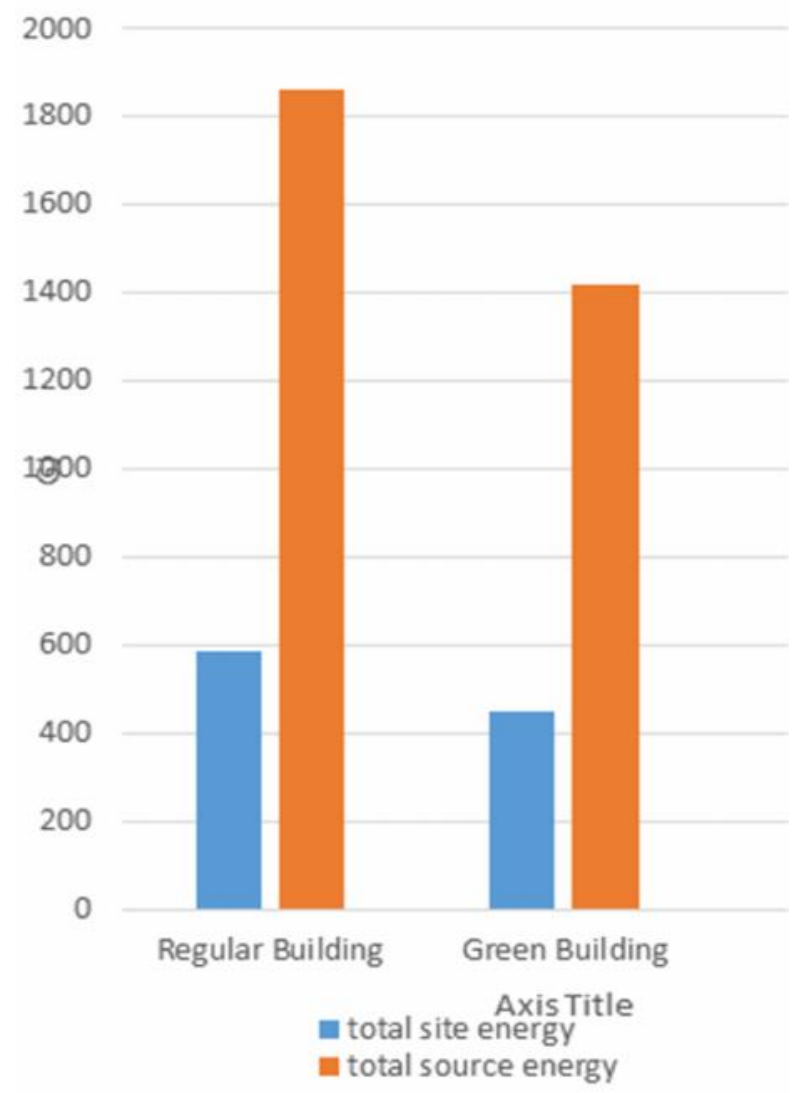

Fig. 5 Annual Building Utility Performance Summary-Site and Source Energy (GJ) 


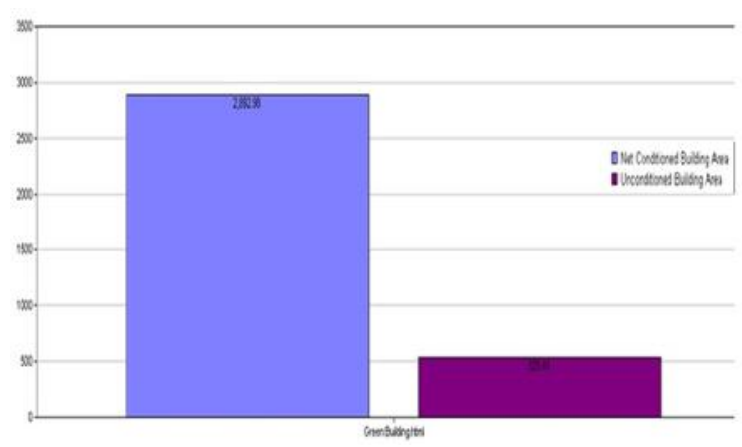

Fig .6 Conditioned and Unconditioned Building Area $\left(\mathbf{M}^{2}\right)$.

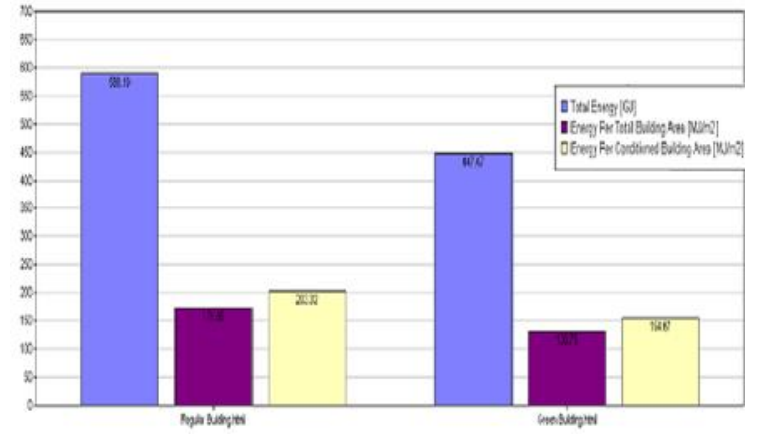

Fig. 7 Energy consumed per Area vs Total Energy

It is found that converting the building from regular to green will save $23.9 \%$ of Energy consumption. Figure 8 desplays the deffirences between Green and Regular building electricity consumption and intensity in main fields. Since electricity is the only type of power used. Figures 8 and 9 desplay the annual end uses deffirence separately for heating, cooling.

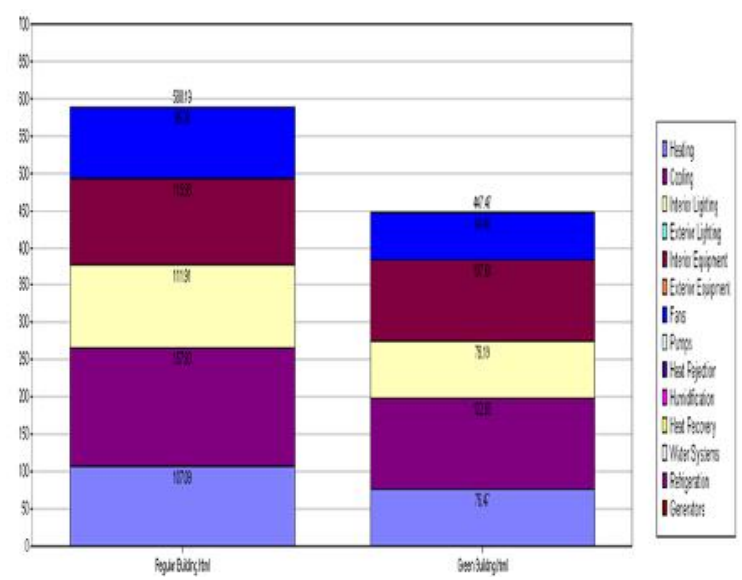

Fig. 8 Annual Electricity Consumption for Both Buildings

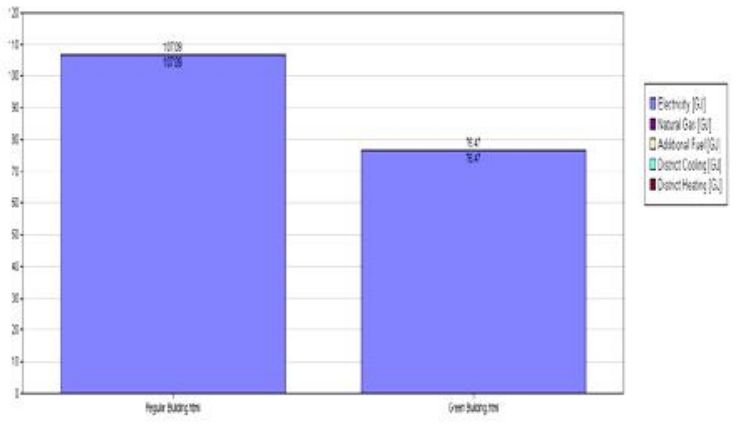

Fig. 9 Annual Heating End Uses

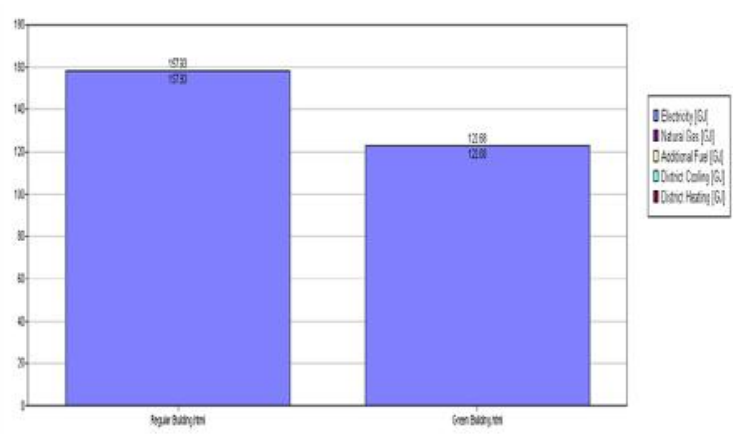

Fig. 10 Annual Cooling End Uses

\section{Energy for each Zone}

to increase natural lighting and heating, increasing the exposure of windows to sunlight is a must. In addition to maximize the glass areas relative to walls. Figure 11 desplays windows-walls ratio for each side of the building. Mentioning that LEED rates include points for high window-wall ratios.

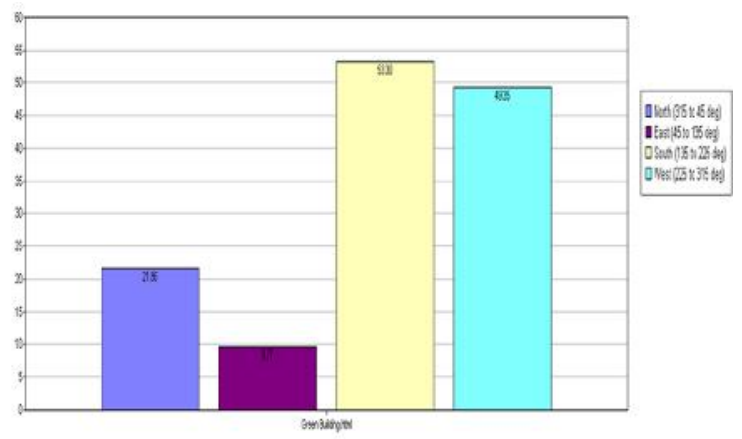

Fig. 11 Window-Wall Ratio Percentage Side-By-Side Bars

A "zone" is a thermal, not a geometric, concept. A "zone" is an air volume at a uniform temperature plus all the heat transfer and heat storage surfaces bounding or inside of that air volume. EnergyPlus calculates the energy required to maintain each zone at a specified temperature for each hour of the day. Since EnergyPlus performs a zone heat balance, the Overall scheme/methodology for running EnergyPlus A Methodology for Using Energyplus. Figure 12 desplays Areas for each zone. 


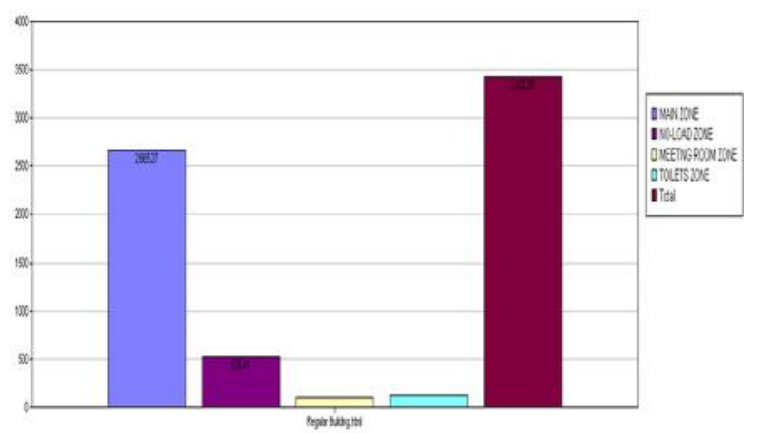

Fig. 12 Areas for Each Zone

Comparing calculated design cooling and heating loads for each zon. Notice that Cooling is always higher than Heating.as shown in the folowing Figures.13 and 14.

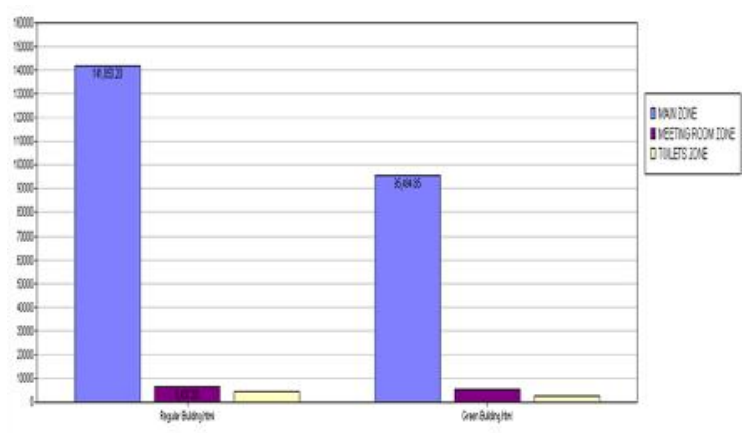

Fig. 13 Calculated Design Cooling Load (W) for Each Zone

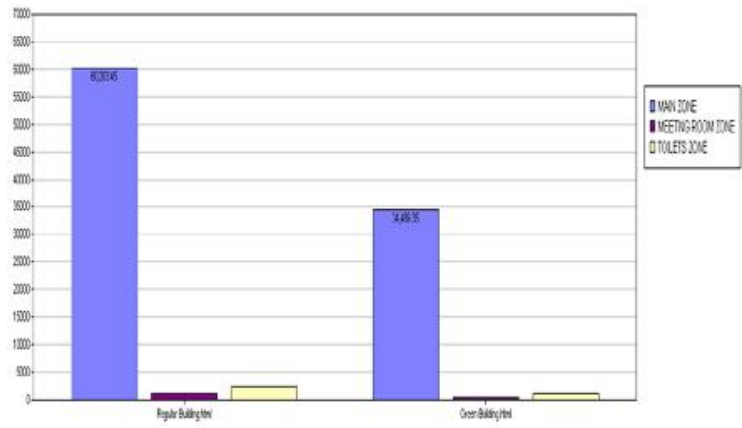

Fig. 14 Calculated Design Heating Load (W) for Each Zone

\section{Heating and Cooling Loads}

Annual Heating and Cooling loads are obtained for both regular and green buildings using HAP software as shown in Figures 15 and 16.

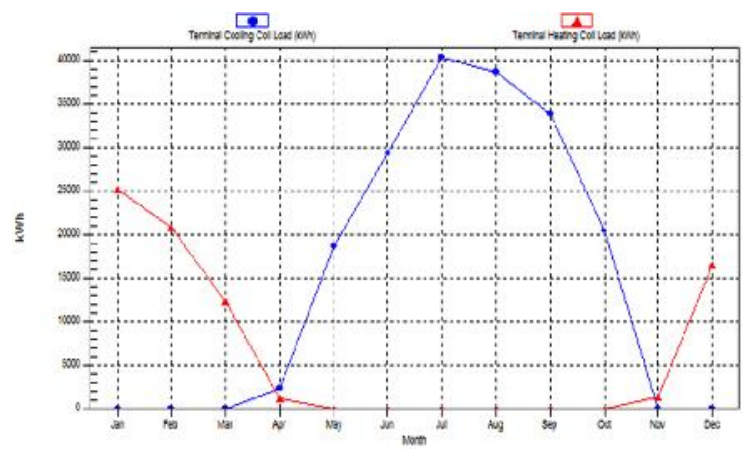

Fig15 Cooling and Heating Loads during One Year for the Regular Building

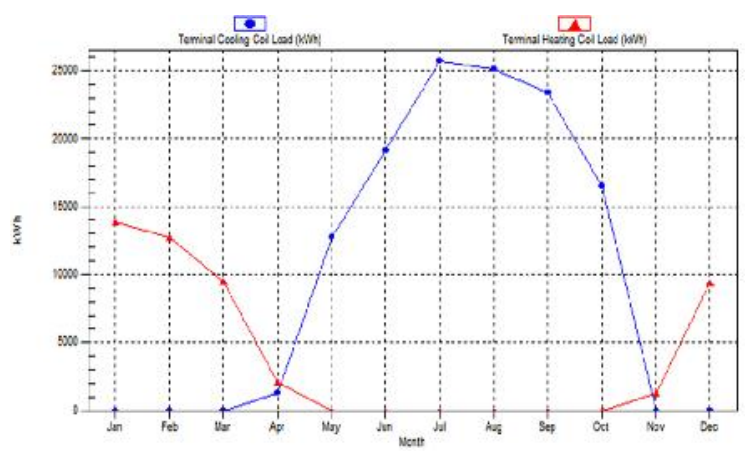

Fig. 16 Cooling and Heating Loads during One Year for Green Building

\section{Conclusions}

- $\quad$ Energy saving

It is found that Cooling takes the highest percentage of Energy consumed. And that what WHO designers noticed as well. Therefore, they put in mind using good insulation materials i.e. extruded polystyrene foam in addition to low over-all coefficient of heat transfer windows.

By adding extruded polystyrene foam as an insulation material in wall instead of air only, using improved windows and limiting lighting and equipment, they saved $23.9 \%$ of total Site energy.

Moreover, one of the most important measures was selecting VRF system as a convenient HVAC system.

By using VRF system, energy savings of up to $55 \%$ are predicted over comparable unitary equipment in some buildings. ${ }^{[7]}$

- Orientation

It is also found that the orientation has a major effect on energy consumption, as improving natural lighting, which is more comfortable for the occupants, and maximizing the sunlight enters the building especially in winter by using coated windows and the diffusers that were installed to avoid that in summer. 
- Environmental impacts

1. $\mathrm{CO} 2$

Jordan power plants usually use heavy fuel oil, diesel or natural gas to generate electricity, and as studies say: to generate I kWh of electricity using diesel in the power plant that produce 821 grams of $\mathrm{CO} 2$ emissions and generating it using natural gas produce 465 grams of $\mathrm{CO} 2$

WHO saves $123791.67 \mathrm{kWh}$ off the total source energy that will decrease $57563.12 \mathrm{~kg}$ if naturel gaswas used in the power plant and saves $101632.96 \mathrm{~kg}$ if diesel or heavy fuel oil was used.

\section{Water}

In WHO a high efficient tabs and toilets had used they used a toilets that consumes 3.5 liter per flush and a tabs that consume 3 liter per minute and all of it working by LASER motion detectors, they also installed drain water collectors for irrigating the plants.

\section{Noise pollution}

As the WHO building located in one of the most traffic streets in Amman, the resultant noise will affect the productivity of the employees so designers could not turn a blind eye for such issue, so that glass they used was also good in insulating acoustic noise.

\section{- $\quad$ Feasibility}

As WHO building is a LEED gold-certificated building, typical payback period of 5-10 years is a required condition. Tables $(1$, 2 , and 3) below show insolation, regular and advanced glasses and money saved from energy saving, respectively

Table 1 Insulation Cost

\begin{tabular}{|l|l|l|l|l|}
\hline $\begin{array}{l}\text { Thickness } \\
(\mathrm{m})\end{array}$ & $\begin{array}{l}\text { Gross } \\
\text { wall area } \\
\left(\mathrm{m}^{2}\right)\end{array}$ & $\begin{array}{l}\text { Insolation } \\
\text { volume } \\
\left(\mathrm{m}^{3}\right)\end{array}$ & $\begin{array}{l}\text { Price } \\
\text { JD/ } \mathrm{m}^{3} \\
{[16]}\end{array}$ & Price JD \\
\hline 0.05 & 1749.08 & 87.454 & 85 & 7433.59 \\
\hline
\end{tabular}

Table 2 Glass Costs

\begin{tabular}{|l|l|l|l|}
\hline $\begin{array}{l}\text { U-value of } \\
\text { Glass } \\
\mathrm{W} /\left(\mathrm{m}^{2} \mathrm{~K}\right)\end{array}$ & $\begin{array}{l}\text { Total } \\
\text { windows area } \\
\left(\mathrm{m}^{2}\right)\end{array}$ & $\begin{array}{l}\text { Price JD/m } \\
{[17]}\end{array}$ & Price JD \\
\hline 1.9 & 598.04 & 79 & 47245.16 \\
\hline 3.5 & 598.04 & 43 & 25715.72 \\
\hline
\end{tabular}

Table 3 Annual Energy Cost Saving

\begin{tabular}{|c|c|c|c|c|c|}
\hline $\begin{array}{c}\text { Total } \\
\text { Site } \\
\text { energy } \\
\text { for } \\
\text { regular } \\
\text { building } \\
\text { GJ /year }\end{array}$ & $\begin{array}{c}\text { Total } \\
\text { Site } \\
\text { energy } \\
\text { for green } \\
\text { building } \\
\text { GJ /year }\end{array}$ & $\begin{array}{c}\text { Saved } \\
\text { Energy } \\
(\mathrm{GJ}) / \text { year }\end{array}$ & $\begin{array}{c}\text { Saved } \\
\text { Energy } \\
(\mathrm{kWh}) / \text { year }\end{array}$ & $\begin{array}{c}\text { Tariff } \\
(\mathrm{JD} / \mathrm{kWh})\end{array}$ & $\begin{array}{c}\text { Total } \\
\text { saving } \\
\mathrm{JD} / \text { year }\end{array}$ \\
\hline 588.19 & 447.47 & 140.72 & 39088.89 & 0.127 & 4964.289 \\
\hline
\end{tabular}

As shown in tables above, total insolation cost is: (47245.16 25715.72) $+7433.59=28963.03 \mathrm{JD}$

Therefore, the payback period will be: (28963.03 JD) / (4964.289 JD/year) $=5.8$ years which is in the range. Finally, as it was shown above, green building is an effective way to save energy and reduce damages on the environment. With the increased demand on energy and with exhaustion of our energy sources, the green buildings will be globally popular and in the next years, common buildings will be replaced by it.

The Green Building concept is counted as point for the mankind, it is not just saving money or saving energy, sources or environment, it will make all previous more tangible for who's working, visiting or even passing next to such building, it will make a more responsible generation than us, so they could save the mother nature more than we did.

\section{References}

[1] Hingham.ma.lwvent.org/files/impact_on_environment. pdf $(12 / 5 / 2014)$

[2] http://en.wikipedia.org/wiki/Leadership_in_Energy_an d_Environmental_Design\#cite_note-11

[3] http://www.enermodal.com/leed-explained.html

[4] Google earth

[5] Jordan Green Building council: http://www.jordangbc.org/index.php/92-press/138who-building-awarded-leed-gold-certificate

[6] Jordan Green Building Guide. $1^{\text {st }}$ edition Published in 2013.

[7] Thornton, Brian (December 2012). "Variable Refrigerant Flow". General services

[8] http://www.gsa.gov/portal/content/140967

[9] Goetzler Systemd. ASHRAE Jourbal: 24-31

[10] http://www.aircoolsystemsuk.co.uk/images/vrf-vrvdiagram.jpg gathered in (03/may/2014)

[11] Apps1.eere.energy.gov/building/energyplus/energyplus _about.cfm 